Published by LPMP Imperium

Journal homepage: https://ejournal.imperiuminstitute.org/index.php/JMSAB

\title{
FAKTOR PEMBENTUK BRAND LOVE, WORD OF MOUTH, DAN REPURCHASE INTENTION ATAS PRODUK HEDONIS: TELAAH PADA PELANGGAN PRODUK GUNPLA MEREK BANDAI
}

\author{
1Aditya Tri Nugroho, ${ }^{2}$ Whony Rofianto*, \\ ${ }^{3}$ Surachman Surjaatmadja, ${ }^{4}$ Meta Andriani \\ 1234 Manajemen, Fakultas Ekonomi, STIE Indonesia Banking School \\ Jalan Kemang Raya No.35, Jakarta, Indonesia, 12730 \\ *Email korespondensi: rofianto@ibs.ac.id
}

\begin{abstract}
This study aims to analyze the factors that influence brand love, as well as its implications for word of mouth, and repurchase intention. Rooted in the theory of interpersonal love and relationships, this research is an expansion of previous research models by accommodating aspects of brand community, brand experience and price perception. Empirical data was collected through an online survey of 100 samples of Bandai Gunpla consumers living in Indonesia. Hypothesis testing is done through Partial Least Square Structural Equation Modeling (PLS-SEM) approach. Based on the estimation of the structural model that has been carried out, the results show that self-expressiveness has a positive effect on brand love, brand trust has a positive effect on brand love, brand community has a positive effect on brand love, brand love has a positive effect on WOM and e-WOM, brand love has a positive effect on repurchase intention and brand experience has a positive effect on repurchase intention. Meanwhile, the hypothesis of the positive effect of hedonic products on brand love and price perception on repurchase intention was not proven in this study.
\end{abstract}

Keyword: Brand love, Word of mouth (WOM), Electronic word of mouth (E-WOM), Repurchase intention, Hedonic product

Whony Rofianto

Manajemen, Fakultas Ekonomi, STIE Indonesia Banking School

Jalan Kemang Raya No.35, Jakarta, Indonesia, 12730

*Email: rofianto@ibs.ac.id

Research

Paper

Management

Received: 25

September

2021

Accepted: 04

November

2021

Online: 31 Des

2021

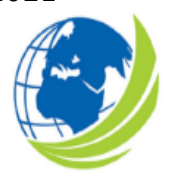

Jurnal

Manajemen

Strategi dan

Aplikasi

Bisnis,

Vol 4, No. 2,

2021,

pp. 496 - 507

eISSN 2655-

237X

(C) The Author(s) 2021

DOI: $10.36407 /$ jmsab.v4i2.441

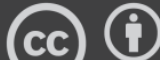

CC BY: This license allows reusers to distribute, remix, adapt, and build upon the material in any medium or format, so long as attribution is given to the creator. The license allows for commercial use. 


\section{PENDAHULUAN}

Perkembangan teknologi yang cepat di era globalisasi ini mendorong terciptanya berbagai alat canggih di segala bidang, termasuk pada bidang produksi yang dapat mendorong percepatan suatu kegiatan produksi dalam skala besar, mendorong tingkat persaingan antar merek yang semakin sengit. Oleh sebab itu, dalam menghadapi persaingan yang ketat dalam kegiatan bisnis, suatu merek sudah seharusnya melakukan perencanaan yang berfokus pada tingkat kepuasan dari konsumen, karena konsumen adalah pelaku penting dalam kegiatan konsumsi. Kegiatan pemasaran bertujuan untuk mempengaruhi sikap dari konsumen maupun calon konsumen untuk bersedia membeli produk yang ditawarkan oleh suatu merek ketika produk tersebut sudah dipasarkan. Faktor penting dalam menciptakan nilai tersebut adalah produksi, pemasaran, dan konsumsi. Pemasaran merupakan penghubung pada kegiatan produksi dan konsumsi (Hartono, Hutomo, \& Mayangsari, 2012). Dengan menyediakan produk atau jasa yang sesuai dengan keinginan dan harapan konsumen dapat mendorong keberlangsungan suatu merek. Oleh sebab itu, suatu merek perlu menciptakan suatu produk yang akan dicintai oleh konsumen, memiliki sesuai dengan keinginan dan kebutuhan konsumen seperti dengan menciptakan produk yang memiliki nilai yang sejajar dengan self-expressiveness pada konsumen. Dalam suatu penelitian diungkapkan bahwa konsumen dapat mengalami keterikatan secara emosional yang mendalam terhadap merek tertentu (Albert \& Merunka, 2013).

Pada penelitian terdahulu mengungkapkan fakta bahwa ketertarikan emosional (brand love) pada pelanggan terhadap suatu merek dapat dijadikan ukuran dari kekuatan pada suatu merek dan harus menjadi tujuan utama pada kegiatan manajemen atau pemasaran pada suatu merek sehingga dapat menciptakan ketertarikan secara emosional pada konsumen (Pawle \& Cooper, 2006). Telah diketahui pada penelitian sebelumnya bahwa nilai hedonis pada suatu produk dapat memengaruhi brand love (Karjaluoto, Munnukka, \& Kiuru, 2016). Sehingga pada penelitian ini akan memfokuskan pembentukan brand love atas produk hedonis. Pada penelitian sebelumnya terdapat keterbatasan, yaitu tidak secara spesifik menentukan jenis merek yang diteliti, namun memberikan kesempatan pada responden untuk mengekspresikan jenis merek hedonis yang responden kenal. Pada penelitian ini penulis secara spesifik menentukan jenis merek yang akan di teliti yaitu pada produk Gunpla (Gundam Plastic Model) dari merek Bandai.

Penelitian ini berusaha menjawab keterbatasan dan saran pada penelitian sebelumnya (Karjaluoto et al., 2016) dengan melalukan uji pada konteks yang berbeda yang dinilai relevan dengan konstruk hedonic product. Penelitian ini juga berupaya memenuhi harapan untuk menelaah efek dari komunitas merek (brand community) yang belum diakomodasi pada model penelitian sebelumnya. Lebih jauh lagi, pada penelitian ini juga ditambahkan variabel repurchase intention sebagai variabel endogen dari variabel brand love. Penelitian ini juga melakukan modifikasi berupa penempatan variabel brand experience dan price perception terhadap repurchase intention. Pada penelitian sebelumnya dikatakan bahwa brand love merupakan tujuan akhir dari hubungan pelanggan dengan merek (Karjaluoto et al., 2016). Pada penelitian ini peneliti ingin menguji lebih jauh hingga pada tahap repurchase intention ketika seorang konsumen telah mencintai suatu merek, serta mengkaji pengaruh dari variabel price perception dan brand experience dalam pembentukan repurchase intention pada konsumen. Dengan demikian, penelitian ini bertujuan untuk menguji faktor-faktor pembentuk brand love, serta implikasinya terhadap word of mouth, dan repurchase intention pada konteks produk hedonis Gunpla merek Bandai, dengan mengikutsertakan konstruk brand community, brand experience dan price perception. 


\section{KAJIAN PUSTAKA}

Self-expressiveness dapat didiskusikan dalam karakteristik aktivitas seperti aktivitas ekspresi diri seperti dengan cara aktivitas hedonis atau sejauh mana seseorang dapat mengalami perasaan ekspresi diri saat terlibat dalam suatu aktivitas (Sirgy et al., 2016). self-expressiveness atau ekspresi diri ini merupakan cerminan dari citra diri seseorang yang menggambarkan bagaimana kepribadian seseorang yang dalam kegiatan konsumsi suatu merek dapat menggambarkan diri seseorang (Wallace, Buil, \& de Chernatony, 2014) Pada penelitian terdahulu menunjukkan bahwa suatu merek dapat mendorong konsumen untuk mengekspresikan diri mereka dan menimbulkan rasa cinta pada suatu merek (Karjaluoto et al., 2016).

H1: Self-expressiveness memiliki pengaruh positif pada brand love.

Brand trust merupakan bentuk kepercayaan dari konsumen pada suatu merek tertentu yang diartikan sebagai suatu bentuk keinginan dari konsumen untuk dapat mempercayai suatu merek tersebut dan termasuk juga dengan risiko yang mungkin akan dihadapi oleh konsumen atas ekspektasi dari penggunaan merek tersebut (Hasugian, 2015). Brand trust terdiri dari pengalaman pada merek di masa lalu dan juga harapan konsumen pada masa depan, sehingga brand trust memiliki keterkaitan positif terhadap brand love (Karjaluoto et al., 2016).

$\mathrm{H} 2$ : Brand trust memiliki pengaruh positif terhadap brand love.

Nilai hedonic product memberikan pengalaman afektif dan indrawi dari estetika, kesenangan sensual, fantasi dan kesenangan yang dirasakan oleh konsumen (Karjaluoto et al., 2016). Dalam penelitian sebelumnya, nilai hedonis pada suatu produk (hedonic product) ditemukan sangat memengaruhi kecintaan merek (Batra, Ahuvia, \& Bagozzi, 2012).

H3: Nilai hedonic suatu produk memiliki pengaruh positif terhadap brand love.

Brand community dapat didefinisikan sebagai bentuk motivasi intrinsik pada konsumen untuk berinteraksi dan bekerjasama dengan anggota komunitas (Algesheimer, Dholakia, \& Herrmann, 2005). brand community memiliki efek positif pada kecintaan merek (brand love), terutama pada sisi identifikasi dalam komunitas berbasis jaringan online (keterlibatan interaktif sosial) dapat meningkatkan hubungan afektif antara konsumen dengan merek (Coelho, Bairrada, \& Peres, 2019).

H4: Ada hubungan positif antara Brand Community dan Brand Love.

Brand love didefinisikan sebagai tingkat keterikatan emosional pada konsumen yang penuh gairah terhadap suatu merek. Brand love berfungsi untuk lebih efektif dalam upaya memprediksi variabel utama seperti niat pembelian kembali (repurchase intention). Brand love dianggap dapat secara langsung memprediksi terjadinya WOM yang positif. Word of mouth (WOM) merupakan bentuk rekomendasi yang bersifat pribadi dari mulut ke mulut yang berkaitan dengan komunikasi interpersonal, komunikasi informal dan periklanan informal (Goyette I., Ricard, J., \& F., 2010). Brand love juga berperan sebagai mediator antara variabel self-expressiveness, trust dan hedonic product dengan WOM (Karjaluoto et al., 2016).

H5: Brand love memiliki pengaruh positif terhadap WOM.

Perkembangan kegiatan word of mouth (WOM) dengan menggunakan unsur dari internet dikenal sebagai electronic word of mouth (e-WOM) (Firdaus \& Abdullah, 2017). E-WOM umumnya merupakan komunikasi secara tertulis di media sosial atau internet, sedangkan WOM umumnya dilakukan secara lisan dari mulut ke mulut. Oleh sebab itu, maka WOM dan eWOM dibedakan, namun keduanya dikonseptualisasikan sebagai bentuk konsekuensi dari bentuk kecintaan konsumen pada suatu produk, jasa, dan merek (Carroll \& Ahuvia, 2006). Telah dibuktikan pula pada penelitian sebelumnya bahwa terdapat hubungan positif yang kuat antara variabel brand love dengan variabel WOM dan e-WOM. (Karjaluoto et al., 2016). H6: Brand love memiliki pengaruh positif terhadap e-WOM.

Brand love juga dapat memengaruhi loyalitas pada konsumen terhadap suatu merek dan menciptakan niat untuk membeli kembali (repurchase intention) pada konsumen terhadap suatu produk (Han, Yu, Chua, Lee, \& Kim, 2019). Brand love dapat menjadi mediator antara 
variabel hedonic product dengan variabel purchase ataupun repurchase intention. (Rodrigues \& Rodrigues, 2019).

H7: Brand love memiliki pengaruh positif terhadap Repurchase Intention.

Repurchase intention itu ditemukan sebagai hasil positif dari kepuasan konsumen dan nilai yang dirasakan oleh konsumen pada suatu produk ataupun jasa dari suatu merek. Hasil uji pada penelitian lain menunjukkan bahwa ada pengaruh moderasi yang signifikan pada hubungan antara brand experience dan repurchase intention (Han, Lee, Song, Lee, \& Chua, 2019). Brand experience positif yang dirasakan oleh konsumen dapat mempengaruhi niat pembelian kembali pada konsumen dikemudian hari. (Yasri, Susanto, Hoque, \& Gusti, 2020)

H8: Brand Experience secara positif mempengaruhi Repurchase Intention.

Price perception adalah ketika konsumen mempercayai bahwa harga yang ditawarkan oleh sebuah merek memiliki kualitas produk yang sesuai dengan hadapan yang ditawarkan pada konsumen. Pada penelitian lainnya menunjukkan bahwa kewajaran pada price perception memiliki hubungan positif antara harga yang dirasakan oleh konsumen dengan repurchase intention (Suhaily \& Soelasih, 2017). Pada penelitian lain telah ditemukan juga bahwa adanya hubungan antara variabel price perception dengan variabel repurchase intention. Dalam domain pemasaran, pada studi yang ada juga menunjukkan bahwa price perception secara positif mempengaruhi repurchase intention (Yasri et al., 2020).

H9: Price Perception secara positif mempengaruhi Repurchase Intention.

\section{METODE}

Pada penelitian ini objek yang dikaji adalah konsumen produk hedonik Gunpla (Gundam Plastic Model) yang berdomisili di wilayah Indonesia yang merupakan konsumen atau pernah membeli produk Gunpla dari merek Bandai dan tergabung dalam komunitas Gundam. Pada penelitian ini menggunakan metode deskriptif kuantitatif. Penelitian deskriptif bertujuan untuk menguraikan sesuatu, umumnya terkait karakteristik dan fungsi dari pasar. Data yang dipergunakan dalam penelitian ini merupakan data cross sectional yang lazim dipergunakan pada desain penelitian deskriptif (Malhotra \& Peterson, 2001). Pengumpulan data dilakukan dengan pendekatan survei melalui kuesioner yang disebarkan kepada responden secara daring melalui google form. Ringkasan pernyataan yang dipergunakan pada kuesioner untuk masing-masing variabel beserta sumber rujukannya disajikan pada Tabel 1 . Hasil yang diperoleh dari survei tersebut kemudian diolah dengan menggunakan pendekatan Partial Least Square Structural Equation Modeling (PLS-SEM) dengan menggunakan software SmartPLS 3. Aturan praktis pada tipe analisis tersebut mensyaratkan ukuran sampel minimum adalah 10 kali jumlah maksimum panah yang menunjuk pada variabel pada model penelitian (Hair, Hult, Ringle, \& Sarstedt, 2017), yang dalam penelitian ini berarti adalah $10 \mathrm{x}$ 4 (panah terbanyak yang menuju variabel endogen) $=40$.

Tabel 1. Operasional Variabel

\begin{tabular}{|c|c|c|}
\hline Konstruk & Indikator & Sumber \\
\hline $\begin{array}{l}\text { Self- } \\
\text { Expressiveness }\end{array}$ & $\begin{array}{l}\text { Produk Gunpla merek BANDAI melambangkan pribadi saya yang } \\
\text { sebenarnya. } \\
\text { Produk Gunpla merek BANDAI mencerminkan kepribadian saya. } \\
\text { Produk Gunpla merek BANDAI merupakan perwujudan perasaan } \\
\text { batin saya. } \\
\text { Produk Gunpla merek BANDAI mencerminkan diri Saya yang } \\
\text { sebenarnya. } \\
\text { Produk Gunpla merek BANDAI berdampak positif pada apa yang } \\
\text { dipikirkan orang lain tentang saya. }\end{array}$ & $\begin{array}{l}\text { (Karjaluoto } \\
\text { et al., 2016) }\end{array}$ \\
\hline Brand Trust & $\begin{array}{l}\text { Saya percaya Produk Gunpla merek BANDAI. } \\
\text { Saya mengandalkan Produk Gunpla merek BANDAI. } \\
\text { Produk Gunpla merek BANDAI tidak pernah mengecewakan saya. } \\
\text { Membeli Produk Gunpla merek BANDAI memberi saya ketenangan } \\
\text { pikiran. }\end{array}$ & $\begin{array}{l}\text { (Karjaluoto } \\
\text { et al., 2016) } \\
\text { (Kwon, Jung, } \\
\text { Choi, \& Kim, } \\
\text { 2020) }\end{array}$ \\
\hline
\end{tabular}




\begin{tabular}{|c|c|c|}
\hline Konstruk & Indikator & Sumber \\
\hline $\begin{array}{l}\text { Hedonic } \\
\text { Products }\end{array}$ & $\begin{array}{l}\text { Produk Gunpla merek BANDAI berfungsi / membahagiakan. } \\
\text { Produk Gunpla merek BANDAI berkualitas / menggembirakan } \\
\text { Produk Gunpla merek BANDAI Berguna / menyenangkan. } \\
\text { Produk Gunpla merek BANDAI awet/indah. }\end{array}$ & $\begin{array}{l}\text { (Karjaluoto } \\
\text { et al., 2016) }\end{array}$ \\
\hline $\begin{array}{l}\text { Brand } \\
\text { Community }\end{array}$ & $\begin{array}{l}\text { Saya memiliki ikatan yang kuat dengan orang lain yang juga } \\
\text { konsumen Produk Gunpla merek BANDAI. } \\
\text { Saya merasa sangat mudah untuk menjalin ikatan dengan } \\
\text { konsumen Produk Gunpla merek BANDAI. } \\
\text { Saya merasa terhubung dengan sesama konsumen Produk Gunpla } \\
\text { merek BANDAI. } \\
\text { Ada perasaan persahabatan yang kuat antara saya dan orang lain } \\
\text { yang menggemari Produk Gunpla merek BANDAI. }\end{array}$ & $\begin{array}{l}\text { (Palazon, } \\
\text { Delgado- } \\
\text { Ballester, \& } \\
\text { Sicilia, 2019) }\end{array}$ \\
\hline Brand Love & $\begin{array}{l}\text { Produk Gunpla merek BANDAI membuat saya sangat bahagia. } \\
\text { Saya mencintai Produk Gunpla merek BANDAI. } \\
\text { Saya tidak punya perasaan khusus tentang Produk Gunpla merek } \\
\text { BANDAI. } \\
\text { Saya sangat menyukai Produk Gunpla merek BANDAI. } \\
\text { Saya merasa sangat terikat dengan Produk Gunpla merek BANDAI. }\end{array}$ & $\begin{array}{l}\text { (Karjaluoto } \\
\text { et al., 2016) }\end{array}$ \\
\hline Word of Mouth & $\begin{array}{l}\text { Saya telah merekomendasikan Produk Gunpla merek BANDAI. } \\
\text { Saya sering membicarakan Produk Gunpla merek BANDAI dengan } \\
\text { teman-teman saya. } \\
\text { Saya sering menyebarkan perkataan baik tentang Produk Gunpla } \\
\text { merek BANDAI. } \\
\text { Saya sering menyampaikan informasi positif tentang Produk } \\
\text { Gunpla merek BANDAI kepada orang lain. }\end{array}$ & $\begin{array}{l}\text { (Karjaluoto } \\
\text { et al., 2016) }\end{array}$ \\
\hline $\begin{array}{l}\text { Electronic } \\
\text { Word of Mouth }\end{array}$ & $\begin{array}{l}\text { Saya sering "membicarakan" produk Gunpla merek BANDAI di } \\
\text { lingkungan online. } \\
\text { Saya sering menyebarkan informasi positif atas Produk Gunpla } \\
\text { merek BANDAI melalui Internet. } \\
\text { Saya mencoba menyebarkan ulasan baik tentang Produk Gunpla } \\
\text { merek BANDAI di internet jika ada kesempatan. }\end{array}$ & $\begin{array}{l}\text { (Karjaluoto } \\
\text { et al., 2016) }\end{array}$ \\
\hline $\begin{array}{l}\text { Repurchase } \\
\text { Intention }\end{array}$ & $\begin{array}{l}\text { Saya berniat membeli produk Gunpla dari merek BANDAI di masa } \\
\text { mendatang. } \\
\text { Saya selalu tertarik untuk membeli lebih banyak produk Gunpla } \\
\text { dari merek BANDAI. } \\
\text { Saya selalu berniat mencari produk Gunpla dari merek BANDAI } \\
\text { meski di luar kota/negeri. } \\
\text { Jika ada kesempatan, saya berniat membeli kembali produk Gunpla } \\
\text { dari merek Bandai. }\end{array}$ & $\begin{array}{l}\text { (Mohammed, } \\
2020) \\
\text { (Hsu, 2017) }\end{array}$ \\
\hline $\begin{array}{l}\text { Brand } \\
\text { Experience }\end{array}$ & $\begin{array}{l}\text { a. Sensory } \\
\text { Produk Gunpla dari merek BANDAI memberi kesan yang kuat } \\
\text { secara visual. } \\
\text { Menurut saya produk Gunpla merek BANDAI menarik secara } \\
\text { visual. } \\
\text { Produk Gunpla merek BANDAI terlihat bagus saat berpose } \\
\text { b. Affective } \\
\text { Produk Gunpla merek BANDAI dapat membangkitkan perasaan } \\
\text { tertentu. } \\
\text { Saya memiliki ikatan emosional yang kuat dengan produk Gunpla } \\
\text { merek BANDAI. } \\
\text { Produk Gunpla merek BANDAI tergolong sebagai emotional brand. } \\
\text { c. Behavioral } \\
\text { Saya sering terlibat dalam aktivitas fisik dengan Produk Gunpla } \\
\text { merek BANDAI. }\end{array}$ & $\begin{array}{l}\text { (Brakus, } \\
\text { Schmitt, \& } \\
\text { Zarantonello, } \\
\text { 2009) }\end{array}$ \\
\hline
\end{tabular}




\begin{tabular}{|c|c|c|}
\hline Konstruk & Indikator & Sumber \\
\hline $\begin{array}{l}\text { Price } \\
\text { Perception }\end{array}$ & $\begin{array}{l}\text { Produk Gunpla merek BANDAI memberikan pengalaman fisik } \\
\text { kepada saya. } \\
\text { Produk Gunpla merek BANDAI merupakan merek yang action } \\
\text { oriented. } \\
\text { d. Intellectual } \\
\text { Saya sering terlibat dalam banyak aktivitas berfikir dengan Produk } \\
\text { Gunpla merek BANDAI. } \\
\text { Produk Gunpla merek BANDAI sering membuat saya berfikir. } \\
\text { Produk Gunpla merek BANDAI sering membangkitkan rasa } \\
\text { keingintahuan Saya } \\
\text { Harga produk Gunpla dari merek BANDAI sesuai dengan kualitas } \\
\text { yang ditawarkan (adil). } \\
\text { Harga produk Gunpla dari merek BANDAI masuk akal. } \\
\text { Harga produk Gunpla dari merek BANDAI berada pada level yang } \\
\text { masih dapat diterima. }\end{array}$ & $\begin{array}{l}\text { (Cakici, } \\
\text { Akgunduz, \& } \\
\text { Yildirim, } \\
\text { 2019) }\end{array}$ \\
\hline
\end{tabular}

\section{HASIL DAN PEMBAHASAN}

Pada penelitian ini data yang digunakan berasal dari 100 sampel responden yang telah melampaui kebutuhan data minimal yang diperlukan pada pengolahan PLS-SEM sebanyak 40 buah data. Responden yang berhasil dihimpun terdiri dari 95\% responden berjenis kelamin pria, sedangkan responden berjenis kelamin wanita sebesar 5\% dari total keseluruhan responden. Mayoritas resonden berusia antara 21-30 tahun dengan persentase sebesar 59\% dari total keseluruhan responden. Dari data tersebut diketahui bahwa mayoritas responden dengan latar belakang pendidikan terakhir yaitu S1/D4 sebesar 48\% dari total keseluruhan responden. Mayoritas responden merupakan seorang karyawan sebesar 37\% dari total keseluruhan responden. Dengan rata-rata pengeluaran perbulan kurang dari Rp1.000.000 sebesar 30\% dari total keseluruhan responden. Dari 15 Provinsi yang tercatat mayoritas responden berasal dari DKI Jakarta sebesar 30\%. Mayoritas responden memiliki lebih dari 20 Gunpla yaitu sebanyak 41 dari 100 responden atau sebesar 41\%. Diketahui bahwa sebesar $82 \%$ responden berinteraksi pada komunitas online, sebesar $37 \%$ responden berinteraksi pada komunitas offline, dan 56\% responden berinteraksi dengan teman-teman/kelompok kecil, serta tidak ada satu pun responden yang tidak memiliki koneksi.

Pada tahap estimasi model pengukuran telah dilakukan proses eliminasi indikator HP4, BL3, BE2, dan BE3 yang mengindikasikan nilai loading factor di bawah 0.7. Setelah proses eliminasi diperoleh inikasi bahwa nilai cronbach's alpha, composite reliability dan average variance extracted telah melampaui sytarat minimal yang disarankan yaitu $0.7,0.7$ dan 0.5 . Hasil estimasi Fornell-Larcker criterion pada model pengukuran juga mengindikasikan bahwa perangkat pengukuran yang dipergunakan pada penelitian ini memiliki derajat discriminant validity yang baik.

Hasil estimasi model struktural mengindikasikan bahwa konstruk endogen brand love memiliki koefisien determinasi sebesar 0.724, WOM sebesar 0.585, EWOM sebesar 0.507 dan repurchase intention sebesar 0.420 . Variabel self-expressiveness terbukti memiliki pengaruh positif terhadap brand love (membuktikan H1) dengan hasil original sample (o) sebesar 0.251 dan $p$ values sebesar 0.003 dengan hasil siginikan. Hal ini serupa dengan hasil dari penelitian terdahulu (Karjaluoto et al., 2016). Hal ini menunjukan bahwa dengan adanya kesamaan antara citra diri yang dimiliki oleh konsumen terhadap suatu merek tertentu dapat mendorong terciptanya rasa cinta pada konsumen terhadap suatu merek yang dapat mengekpresikan citra diri pada konsumen. 


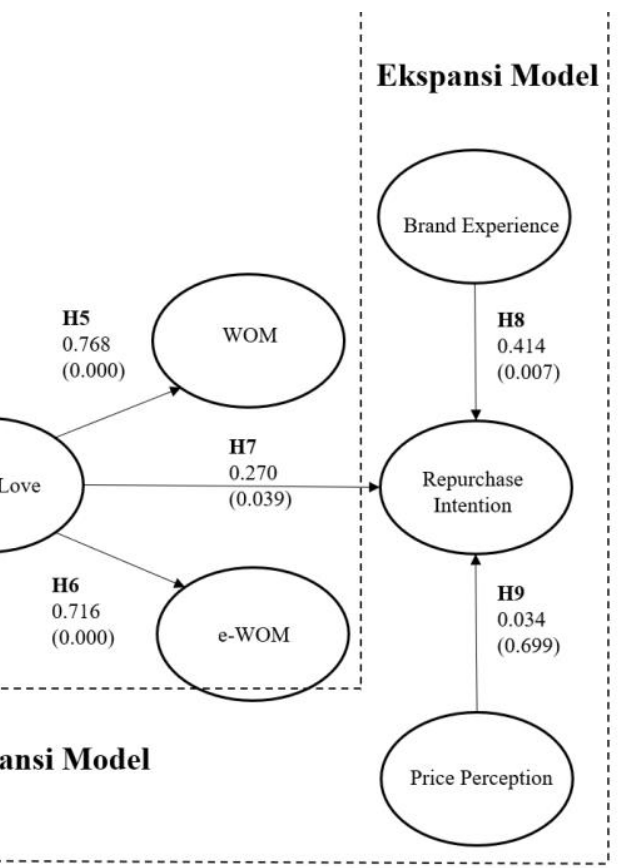

Keterangan Angka:

1. Koefisien regresi dan 2. p-value (dalam kurung)

\section{Gambar 1. Model Penelitian dan Nilai Hasil Estimasi Model Struktural}

Hasil uji data pada jalur $\mathrm{H} 2$ menunjukan adanya hubungan positif pada variabel brand trust dengan variabel brand love dengan hasil original sample (o) sebesar 0.343 dan $p$ values sebesar 0.000 dengan hasil siginikan. Hal ini serupa dengan penelitian terdahulu milik (Karjaluoto et al., 2016) yaitu adanya pengaruh positif dari variabel brand trust terhadap brand love. Hal ini membuktikan bahwa dengan adanya suatu kepercayaan yang dimiliki oleh konsumen terhadap suatu merek tertentu dapat meningkatkan rasa cinta dari konsumen terhadap suatu merek tersebut.

Berdasarkan hasil uji data pada jalur H3 diperoleh fakta bahwa tidak ada hubungan dari variabel hedonic product terhadap brand love dengan hasil uji data original sample (o) sebesar 0.061 dan $p$ values 0.364 dengan hasil tidak signifikan. Hasil ini berbeda dengan penelitian sebelumnya milik (Karjaluoto et al., 2016) yang menunjukan adanya hubungan positif antara hedonic product dengan brand love. Penulis berpendapat bahwa keterangan tidak signifikan terjadi karena imbanganya pendapat pada jawaban dari kuesioner terkait persepsi nilai hedonik atau utilitarian pada produk Gunpla merek Bandai. Meski hasil pilot study menunjukan hasil bahwa produk Gunpla merupakan produk hedonis akan tetapi tidak sedikit juga konsumen yang beranggapan bahwa produk Gunpla juga memiliki fungsi. Berdasarkan pengamatan peneliti di lapangan sebagai seorang penghobi Gunpla, peneliti berpendapat bahwa produk Gunpla merupakan produk hedonis dan tersier yang dicintai oleh konsumennya, meski Gunpla memiliki harga yang mahal dan bukan sebuah produk yang melengkapi kebutuhan primer ataupun sekunder, rasa cinta konsumen Gunpla sangat tinggi hingga secara sukarela membayar harga mahal, mengikuti pre-order, dan aktif memberikan ulasan positif, serta membuat komunitas khusus Gunpla merek Bandai. Sehingga peneliti berpendapat, meski hasil olah data Gunpla sebagai hedonic product tidak memiliki hasil signifikan pada brand love akan tetapi secara fakta dilapangan membuktikan bahwa Gunpla merek Bandai merupakan salah satu produk hedonis yang berhasil menciptakan rasa cinta dari konsumennya.

Variabel brand community memiliki pengaruh positif terhadap variabel brand love (membuktikan H4) dengan hasil original sample (o) sebesar 0.376 dan $p$ values sebesar 0.000 sehingga adanya pengaruh positif antara kedua variabel tersebut. Hal ini serupa dengan hasil dari penelitian sebelumnya pada penelitian (Coelho et al., 2019) yang mengatakan bahwa brand community memiliki dampak positif pada brand love, khususnya pada komunitas yang berbasis jaringan yang dapat meningkatkan hubungan antara konsumen dengan konsumen, 
maupun konsumen dengan merek. Pada objek penelitian ini, peneliti sekaligus penghobi yang terlibat dalam komunitas online Gunpla merek Bandai merasakan dengan adanya komunitas terkait Gunpla dapat meningkatkan dan memperoleh pengetahuan, pemahaman, dan informasi terbaru terkait Gunpla, sehingga dengan adanya komunitas ini semakin meningkatkan rasa cinta peneliti terhadap Gunpla khususnya pada merek Bandai.

Hasil pengujian data berikutnya menunjukan hasil nilai original sample (o) sebesar 0.768 dan nilai $p$ values sebesar 0.000 , sehingga dapat disimpulkan bahwa variabel brand love memiliki pengaruh positif terhadap variabel word of mouth (H5 terbukti). Hal ini sejalan dengan hasil penelitian terdahulu yang ditulis oleh (Karjaluoto et al., 2016) yang mengungkapkan bahwa brand love dianggap dapat mendorong terjadinya word of mouth secara positif. Sehingga dapat disimpulkan bahwa dengan kecintaan konsumen terhadap suatu merek dapat mendorong terjadinya pemasaran mulut ke mulut dari konsumen yang telah mencintai suatu merek. Peneliti sebagai seorang konsumen Gunpla yang telah menyukai Gunpla sejak kecil menyetujui hasil dari penelitian tersebut, karena peneliti sering kali mendapati kejadian testimoni positif pada website, blog, media sosial seperti Youtube, Facebook, Instagram, ulasan pada marketplace, dan pada komunitas Gunpla baik secara online maupun offline. Hasil pengujian selanjutnya menunjukan hasil original sampel (o) sebesar 0.716 dan $p$ values sebesar 0.000, sehingga dapat disimpulkan bahwa variabel brand love memiliki pengaruh positif terhadap variabel electronic word of mouth (e-wom) yang berarti membuktikan H6. Hal tersebut sesuai dengan penelitian (Karjaluoto et al., 2016) yaitu terkait pemasaran melalui wom yang menggunakan unsur internet merupakan kegiatan e-wom seperti melakukan wom pada komunitas online atau pada forum jual-beli di media sosisal.

Berdasarkan hasil uji pada jalur $\mathrm{H7}$ dapat diketahui pengaruh dari brand love terhadap repurchase intention memiliki nilai original sample (o) sebesar 0.270 dan $p$ values sebesar 0.039 sehingga secara signifikan kedua variabel tersebut memiliki hubungan positif. Hal ini sesuai dengan penelitian sebelumnya terkait pengaruh dari brand love terhadap repurchase intention pada penelitian (Han, Yu, et al., 2019) yang mengungkapkan bahwa brand love dapat memengaruhi loyalitas pada konsumen sehingga dapat menciptakan niat untuk melakukan pembelian kembali (repurchase intention) pada suatu produk dan merek. Bandai merupakan merek yang berhasil menciptakan loyalitas dan rasa cinta pada konsumennya sehingga memiliki hubungan jangka panjang antara konsumen dengan merek tersebut yang ditandai dengan adanya tindakan pembelian kembali oleh konsumen pada produk Gunpla tersebut. Brand experience terbukti mememiliki pengaruh positif dengan nilai original sample (o) sebesar 0.414 dan $p$ values sebesar 0.007 dengan hasil signifikan terhadap repurchase intention (membuktikan H8). Hasil tersebut sejalan dengan hasil penelitian sebelumnya pada penelitian (Yasri et al., 2020) yang mengunkapkan adanya hubungan brand experience positif yang dirasakan oleh konsumen akan memengaruhi terjadinya niat pembelian kembali pada konsumen. Sehingga pengalaman baik yang dirasakan oleh konsumen merupakan faktor penting untuk menciptakan hubungan jangka panjang antara konsumen dengan suatu merek. Bandai merupakan perusahaan berlisensi resmi dengan jaminan kualitas yang baik sehingga dapat memberikan pengalaman yang maksimal. Berdasarkan studi di lapangan dan pengalaman pribadi peneliti sebagai penghobi dan konsumen Gunpla merek Bandai serta pernah membeli Gunpla dari merek non Bandai, diketahui bahwa kualitas Gunpla dari pihak ketiga yang tidak memiliki lisensi ini memiliki kualitas yang jauh berbeda dari Gunpla produksi merek Bandai, misalnya pada pengalaman proses perakitan Gunpla non Bandai yang seringkali memiliki kecacatan pada produknya (low quality control) dengan kualitas bahan yang membuat tangan terasa sakit pada proses perakitan, serta tampilan box art Gunpla dengan logo non-original yang tidak nyaman untuk dilihat apabila ingin dipajang menurut hasil pilot study yang telah dilakukan oleh peneliti. Sehingga pengalaman yang diberikan oleh Bandai merupakan salah satu faktor penyebab terjadinya repurchase intention pada konsumen merek Bandai.

Sementara itu, pada penelitian ini belum cukup bukti akan ada hubungan antara variabel price perception dengan variabel repurchase intention dengan hasil original sample (o) sebesar 0.034 dan $p$ values sebesar 0.699 dengan hasil keterangan tidak signifikan (H9 tidak terbukti). Hasil ini berbeda dengan penelitian sebelumnya (Yasri et al., 2020). Argumentasi penulis terkait hasil penelitian ini dikarenakan persepsi harga yang ditawarkan oleh merek Bandai tidak mempengaruhi niat membeli kembali pada konsumen Gunpla untuk melengkapi koleksi 
Gunpla tersebut sehingga sesuai dengan istilah "price does not matter" (Daly, 2017). Peneliti sebagai seorang kolektor Gunpla merek Bandai juga memiliki pengalaman terkait harga tidak menghalangi peneliti untuk dapat mengoleksi Gunpla impian peneliti. Sehingga dapat disimpulkan bahwa konsumen merasa puas dengan kualitas yang diberikan oleh merek Bandai yang lebih presisi dibandingkan dengan produk dari merek tiruan, sehingga merupakan hal yang wajar jika harga lebih mahal.

Berdasarkan perbandingan nilai koefisien regresi hasil estimasi model struktural dapat disimpulkan bahwa pembentuk brand love dapat diurutkan berdasarkan variabel yang paling mendominasi yaitu: brand community, brand trust, lalu self-expressiveness. Sementara itu, faktor pembentuk repurchase intention yang paling mendominasi yaitu brand experience kemudian brand love. Disarankan bagi perusahaan produksi produk khususnya produk yang memiliki nilai hedonis untuk melakukan penguatan pada kecintaan konsumen terhadap merek (brand love) melalui pembentukan komunitas, dengan adanya komunitas dapat meningkatkan kepercayaan dan dapat menjadi peluangan untuk melakukan pemasaran. Setalah memperkuat brand love pada konsumen melalui komunitas disarankan juga untuk menguatkan brand love dengan mendapatkan kepercayaaan dari konsumen missal dengan adanya jaminan produk, asuransi, dan quality control yang baik, khususnya pada produksi produk hedonik dengan persepsi harga yang tinggi. Kemudian memperkuat kecintaan merek pada konsumen dengan menyesuaikan citra diri konsumen (self-expressiveness) misalnya dengan membuat produk hedonik yang bisa disesuaikan dengan keinginan konsumen. Selain memperkuat merek melalui kecintaan merek, disarankan untuk mendorong pembentukan niat membeli kembali pada konsumen (repurchase intention) melalui pemberian pengalaman yang maksimal pada konsumen (brand experience) dan memperkuat rasa cinta konsumen terhadap merek tersebut (brand love) guna membentuk rasa ingin membeli kembali pada konsumen. Berdasarkan hasil survey online diketahui bahwa konsumen Gunpla merek Bandai merasakan kebahagiaan, kepuasan, keseruan, dan kepuasan batin setelah melakukan beberapa kali repurchase intention.

\section{KESIMPULAN}

Pada penelitian bertujuan untuk mengetahui faktor pembentuk brand love, word of mouth, electronic word of mouth, dan repurchase intention pada produk hedonis yang melakukan telaah pada konsumen produk Gunpla merek Bandai. Pengolahan data dengan pendekatan PLS-SEM menunjukan hasil yaitu tujuh dari sembilan hipotesis terbukti, sementara itu dua hipotesis belum dapat dibuktikan pada penelitian ini. Secara lebih spesifik penelitian ini membuktikan: 1) variabel self-expressiveness berpengaruh secara positif dan signifikan terhadap variabel brand love, 2) variabel brand trust berpengaruh secara positif dan signifikan terhadap variabel brand love, 3) variabel hedonic product tidak berpengaruh secara signifikan terhadap variabel brand love, 4) variabel brand community berpengaruh secara positif dan signifikan terhadap variabel brand love, 5) variabel brand love berpengaruh secara positif dan signifikan terhadap variabel word of mouth (wom), 6) variabel brand love berpengaruh secara positif dan signifikan terhadap variabel electronic word of mouth (e-wom), 7) variabel brand love berpengaruh secara positif dan signifikan terhadap variabel repurchase intention, 8) variabel brand experience berpengaruh secara positif dan signifikan terhadap variabel repurchase intention, dan 9) variabel price perception tidak berpengaruh secara signifikan terhadap variabel repurchase intention.

Hasil penelitian ini menyimpulkan bahwa faktor pendorong terbentuknya brand love adalah melalui self-expressiveness, brand trust, dan brand community. Sehingga peneliti menyarankan agar pihak perusahaan yang terkait dapat melalukan upaya peningkatan aspek-aspek tersebut guna membangun brand love pada konsumen untuk menciptakan hubungan jangka panjang dan meningkatkan loyalitas konsumen. Terbentuknya brand love, lebih jauh lagi akan dapat mendorong terjadinya word of mouth, electronic word of mouth, dan repurchase intention. Di samping itu, hasil penelitian ini juga mengindikasikan pentingnya upaya memberikan pengalaman (brand experience) yang mendalam kepada konsumen guna meningkatkan peluang terjadinya repurchase intention.

Terlepas dari kontribusi akademis dan praktis yang berusaha disumbangkan melalui penelitian ini, terdapat sejumlah keterbatasan yang membuka peluang dilakukannya penelitian lanjutan terkait konstruk brand love. Pertama, penggunaan skala semantic 
differential dalam pengukuran variabel hedonik produk diduga kurang peka dalam menangkap peran karakteristik hedonic product terhadap brand love karena cenderung bersifat versus question antara hedonik dengan utilitarian. Penelitian lebih lanjut dengan menerapkan skala likert untuk mengukur derajat karakteristik hedonic product mungkin dapat menklarifikasi lebih lanjut pengaruh karakteristik hedonic product terhadap pembentukan brand love. Kedua, peneltian ini bermuara pada word of mouth dan repurchase intention sebagai dampak brand love terhadap merek. Penelitian lebih lanjut dengan akomodasi konstruk terkait pencapaian tujuan konsumen, misalnya positif emotion, diharapkan dapat memperluas penjelasan akan konstruk brand love khususnya dari sisi konsekuensi atau implikasinya.

\section{Daftar Pustaka}

Albert, N., \& Merunka, D. (2013). The role of brand love in consumer-brand relationships. $\begin{array}{llll}\text { Journal of } \quad \text { Consumer } & \text { Marketing, }\end{array}$ https://doi.org/10.1108/07363761311328928

Algesheimer, R., Dholakia, U. M., \& Herrmann, A. (2005). The social influence of brand community: Evidence from European car clubs. Journal of Marketing, 69(3), 19-34. https://doi.org/10.1509/jmkg.69.3.19.66363

Batra, R., Ahuvia, A., \& Bagozzi, R. P. (2012). Brand love. Journal of Marketing, 76(2), 1-16. https://doi.org/10.1509/jm.09.0339

Brakus, J. J., Schmitt, B. H., \& Zarantonello, L. (2009). Brand Experience: What Is It? How Is It Measured? Does It Affect Loyalty? Journal of Marketing, 73(3), 52-68. https://doi.org/10.1509/jmkg.73.3.52

Cakici, A. C., Akgunduz, Y., \& Yildirim, O. (2019). The impact of perceived price justice and satisfaction on loyalty: the mediating effect of revisit intention. Tourism Review, 74(3), 443-462. https://doi.org/10.1108/TR-02-2018-0025

Carroll, B. A., \& Ahuvia, A. C. (2006). Some antecedents and outcomes of brand love. Marketing Letters, 17(2), 79-89. https://doi.org/10.1007/s11002-006-4219-2

Coelho, A., Bairrada, C., \& Peres, F. (2019). Brand communities' relational outcomes, through brand love. Journal of Product and Brand Management, 28(2), 154-165. https://doi.org/10.1108/JPBM-09-2017-1593

Daly, J. (2017). Six Reasons Why Price Does Not Matter. Retrieved from ForbesBooks website: https://www.forbes.com/sites/forbesbooksauthors/2017/06/29/six-reasons-whyprice-does-not-matter/?sh=43723f866b50

Firdaus, T., \& Abdullah, T. (2017). E-WoM: Pengaruhnya terhadap Keputusan Pembelian Tamu Restoran di Bandung Utara. THE Journal: Tourism and Hospitality Essentials Journal, 7(1), 21. https://doi.org/10.17509/thej.v7i1.6843

Goyette I., Ricard, L., J., B., \& F., M. (2010). e-WOM Scale: word-of-mouth measurement scale for e-services context. Canadian Journal of Administrative Sciences/Revue Canadienne Des Sciences de l'Administration, 27(1), 5-23.

Hair, J., Hult, G. T., Ringle, C., \& Sarstedt, M. (2017). A Primer on Partial Least Squares Structural Equation Modeling (PLS-SEM) - Joseph F. Hair, Jr., G. Tomas M. Hult, Christian Ringle, Marko Sarstedt. In Sage.

Han, H., Lee, K.-S., Song, H., Lee, S., \& Chua, B.-L. (2019). Role of coffeehouse brand experiences (sensory/affective/intellectual/behavioral) in forming patrons' repurchase intention. Journal of Hospitality and Tourism Insights, 3(1), 17-35. https://doi.org/10.1108/jhti03-2019-0044

Han, H., Yu, J., Chua, B. L., Lee, S., \& Kim, W. (2019). Impact of core-product and serviceencounter quality, attitude, image, trust and love on repurchase: Full-service vs low-cost carriers in South Korea. International Journal of Contemporary Hospitality Management, 31(4), 1588-1608. https://doi.org/10.1108/IJCHM-05-2018-0376

Hartono, H., Hutomo, K., \& Mayangsari, M. (2012). Pengaruh Strategi Pemasaran Terhadap Peningkatan Penjualan Pada Perusahaan" Dengan Menetapkan Alumni Dan Mahasiswa Universitas Bina Nusantara Sebagai Objek Penelitian. Binus Business Review, 3(2), 882. https://doi.org/10.21512/bbr.v3i2.1271 
Hasugian, J. T. M. (2015). Pengaruh Brand Identity Terhadap Brand Loyalty Melalui Brand Image dan Brand Trust. Jurnal Administrasi Bisnis, 3(4), 923-937.

Hsu, L. C. (2017). Investigating community members' purchase intention on Facebook fan page: From a dualistic perspective of trust relationships. Industrial Management and Data Systems, 117(5), 766-800. https://doi.org/10.1108/IMDS-05-2016-0180

Karjaluoto, H., Munnukka, J., \& Kiuru, K. (2016). Brand love and positive word of mouth: the moderating effects of experience and price. Journal of Product and Brand Management, 25(6), 527-537. https://doi.org/10.1108/JPBM-03-2015-0834

Kwon, J. H., Jung, S. H., Choi, H. J., \& Kim, J. (2020). Antecedent factors that affect restaurant brand trust and brand loyalty: focusing on US and Korean consumers. Journal of Product and Brand Management, (August). https://doi.org/10.1108/JPBM-02-2020-2763

Malhotra, N. K., \& Peterson, M. (2001). Marketing research in the new millennium: Emerging issues and trends. Marketing Intelligence \& Planning, 19(4), 216-232. https://doi.org/10.1108/EUM0000000005560

Mohammed, A. A. (2020). What motivates consumers to purchase organic food in an emerging market? An empirical study from Saudi Arabia. British Food Journal, (March 2019). https://doi.org/10.1108/BFJ-07-2020-0599

Palazon, M., Delgado-Ballester, E., \& Sicilia, M. (2019). Fostering brand love in Facebook brand pages. Online Information Review, 43(5), 710-727. https://doi.org/10.1108/0IR-052017-0175

Pawle, J., \& Cooper, P. (2006). Measuring emotion - Lovemarks, the future beyond brands. Journal of Advertising Research, 46(1), 38-48. https://doi.org/10.2501/S0021849906060053

Rodrigues, C., \& Rodrigues, P. (2019). Brand love matters to Millennials: the relevance of mystery, sensuality and intimacy to neo-luxury brands. Journal of Product and Brand Management, 28(7), 830-848. https://doi.org/10.1108/JPBM-04-2018-1842

Sirgy, M. J., Lee, D. J., Yu, G. B., Gurel-Atay, E., Tidwell, J., \& Ekici, A. (2016). Self-expressiveness in shopping. Journal of Retailing and Consumer Services, 30, 292-299. https://doi.org/10.1016/j.jretconser.2016.02.008

Suhaily, L., \& Soelasih, Y. (2017). What Effects Repurchase Intention of Online Shopping. International Business Research, 10(12), 113. https://doi.org/10.5539/ibr.v10n12p113

Wallace, E., Buil, I., \& de Chernatony, L. (2014). Consumer engagement with self-expressive brands: Brand love and WOM outcomes. In Journal of Product and Brand Management (Vol. 23). https://doi.org/10.1108/JPBM-06-2013-0326

Yasri, Y., Susanto, P., Hoque, M. E., \& Gusti, M. A. (2020). Price perception and price appearance on repurchase intention of Gen Y: do brand experience and brand preference mediate? Heliyon, 6(11), e05532. https://doi.org/10.1016/j.heliyon.2020.e05532 


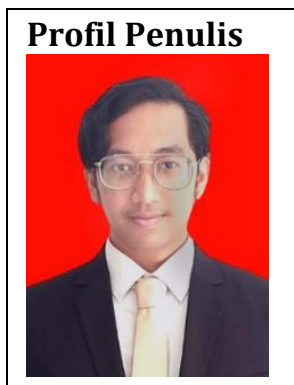

Aditya Tri Nugroho, S.M. merupakan alumni STIE Indonesia Banking School jurusan Manajemen Pemasaran dan mahasiswa tingkat akhir Universitas Terbuka jurusan Ilmu Komunikasi. Penulis memiliki ketertarikan pada penelitian terkait upaya pengembangan Usaha Kecil dan Menengah (UKM) dari segi pemasaran. Penulis dapat dihubungi melalui email koresponden di aditya.nugroho@ibs.ac.id

\section{Dr. Whony Rofia}

membimbing dan melakukan penelitian pada bahasan digital marketing dan sustainability marketing. Korespondensi email: rofianto@ibs.ac.id

Professor Dr. Surachman Surjaatmadja, adalah Profesor di Program Studi Manajemen STIE Indonesia Banking School Jakarta, sejak tahun 2014. Minat Penelitiannya pada bidang Manajemen terutama bidang Manajemen Pemasaran, khususnya pemasaran Perbankan Syariah di Indonesia, disamping penelitian Manajemen Kinerja di UMKM dan Koperasi. Penulis telah menerbitkan beberapa artikel terutama di Jurnal Ilmiah Internasional yang terindeks Scopus baik Q1, Q2, Q3 maupun Q4. Korenspondensi melalui e-mail: surachman.surjaatmadja@ibs.ac.id. atau di isur.atmadja@gmail.com

Meta Andriani, MM merupakan dosen tetap di STIE Indonesia Banking School sejak 2016. Saat ini menjadi pengelola di Program Studi Manajemen STIE Indonesia Banking School selain aktif meneliti di bahasan bidang Manajemen Pemasaran terutama Digital Marketing dan Consumer Behavior. Korespondensi email: meta@ibs.ac.id

\section{Funding}

Kegiatan ini merupakan penelitian gabungan antara mahasiswa dengan dosen yang didanai oleh STIE Indonesia Banking School tahun 2021. 